\title{
Investigating the use of Mediation in Resolving Students' Interpersonal Conflicts in Higher Learning Institutions in Tanzania
}

\author{
Polycarp Africanus Kerega* \\ Lecturer, Institute of Social Work (Department of Labour Studies) Po Box 3375, Dar es Salaam-Tanzania \\ *Corresponding Author: Polycarp Africanus Kerega, Lecturer, Institute of Social Work (Department of \\ Labour Studies) Po Box 3375, Dar es Salaam-Tanzania
}

\begin{abstract}
While mediation is acknowledged as useful in resolving conflicts in wider dimensions including students' interpersonal conflicts in higher leaning institutions; in Tanzania mediation is familiar in resolving labour disputes. Knowledge of whether or not the method is applied in resolving students' interpersonal conflicts in institutions of higher learning is limited. This article explores experiences of deans of students responsible for resolving students' interpersonal conflicts in the higher learning institutions in Tanzania; more particularly, it examines the nature of students' interpersonal conflicts and whether mediation is used in the resolution process. Un-amicably resolved students' interpersonal conflicts are likely to end up into violence which is usually detrimental to quality education delivery, a prerequisite for building an industrial economy, currently aspired in Tanzania. The article reveals the paucity of knowledge and skills in mediation among deans of students. The author recommends imparting knowledge and skills in mediation to both students and deans of students and application of mediation in resolving students' interpersonal conflicts by involving students as peer mediators in the process
\end{abstract}

Keywords: Mediation, Interpersonal Conflicts, Higher Learning Institutions, Peer Mediators

\section{INTRODUCTION}

Interpersonal conflicts have been viewed as inevitable and pervasive wherever human beings are interacting, notably in families, at work places, at institutions of higher learning and elsewhere because of numerous incompatible factors pertaining to individuals' social life such as values, beliefs, goals, perceptions, interests, attitudes, personalities and cultural backgrounds [1:2, 2:599, 3:476].

As commonly understood, interpersonal conflicts denote clash or disagreement between two or more interacting individuals with divergent aspects of social life. Such individuals may be family members, friends, co-workers, students and so forth. Accordingly, interpersonal conflicts usually involve two or more institutional or organisational members of the same or different hierarchical levels or units [4:23]. In that regard, conflict is defined as perceived and / or actual diversity of needs, interests, scarce resources and / or goals between at least two independent parties over task related and /or affective issues, and such differences are manifested through different modes of communication exchanges [5:14, 6:21, 7:279].

Although some authors [see for example 8, 9-12] have attempted to demonstrate the constructive aspects of conflicts, conflicts may have adverse consequences wherever they arise and transform into disputes. However, while numerous scholars including classical thinkers such as Plato and Aristotle warn about the negative consequences of conflicts [1:2], interpersonal conflicts are reported to be prevalent in higher learning institutions around the world [13-15].

Un-amicably resolved interpersonal conflicts are likely to end up into violence which may manifest in various forms such as verbal insults, strikes and fighting [16]. In higher learning institutions, any form of violence is likely to impact upon the quality of education delivery. Poor quality education delivery in Tanzania in particular, is likely to impinge on the current government initiatives towards building an industrial economy in the country [17]. Owing to the negative consequences of conflicts, interest in management of conflict has been stressed not only at work places, but also in other domains including institutions of higher learning. 
Traditional response to disputants or conflicting parties has been punitive measures which include the use of court of law by most superiors such as administrators and teachers [18]. However, evidence shows that punitive measures to aggressive acts cannot teach appropriate behaviour and therefore, have been criticized for being ineffective in the long term [19]. Rather than punitive approaches, recently; alternative dispute resolution approaches have been strongly emphasised. Alternative Dispute Resolution Approaches refer to those processes which are intended to resolve disputes out of court of law, by non-judicial devices [20:282].

In other words, alternative dispute resolution approaches represent a shift from legal or court system to non-coercive processes such as negotiation, conciliation and mediation [21:212]. Mediation is closely similar to conciliation and negotiation except that in conciliation a neutral person acts as a go between for the never meet parties; the parties can be brought together to a point that they can work out their differences without the aid of a third party. On the other hand, negotiation is a two party process whereas mediation is an assisted and facilitated negotiation carried out by a third party [22, 23:11].

Mediation is viewed as a form of assisted negotiation in which an impartial or neutral person facilitates negotiation process in an effort to enable the parties to reach mutually agreeable resolution [1]. As a facilitator of the process, a mediator should have adequate knowledge and skills in mediation to enable good practice of mediation [1].

As a facilitator of the process, the mediator is also not supposed to have a direct interest in conflict or dispute and, should not influence the outcome or make decision. In mediation, decision making is vested upon the disputants who have control over the outcome or solution. For the higher learning institutions, the mediators may be deans of students with requisite knowledge and skills in mediation [5:14, 6:21, 7:279]. However, recently peer mediators have also been involved whereby a neutral or impartial student is sought to assist two or more conflicting students to negotiate an integrative resolution to their conflict [24, 25].

Students' peer mediation process entails enabling students to manage their own conflicts and thereby moving away from punitive methods of behavioural control such as litigation, suspension and discontinuation from studies. Peer mediation is important towards providing students with improved problem solving abilities and multiple opportunities for handling their own problems and hence, avoiding the use of power, force and adjudication methods which are usually viewed as costly and likely to further damage interpersonal relationship [1].

Mediation is usually a voluntary practice although sometimes it may be mandatory or both voluntary and mandatory depending on the legal framework of a particular country. For instance, in Tanzania, as provided by the prevalent labour law: the Employment and Labour Relations (Act No. 6) of 2004, mediation is both voluntary and mandatory. The practice is familiar in resolving labour disputes. As provided by the labour laws in the country: Employment and Labour Relations (Act, No. 6) of 2004 and Labour Institutions (Act, No. 7) of 2004, the disputants may resolve their disputes either through voluntary collective agreement or voluntary arbitration.

When the dispute is resolved through voluntary collective agreement or voluntary arbitration, the parties in dispute are not bound to refer their dispute to the commission for mediation and arbitration (CMA). However, where there is neither collective agreement nor voluntary arbitration, all types of disputes will be referred to the CMA. Upon receipt of the referral dispute, the CMA is required to appoint a mediator to mediate the dispute, decide time, date and place of the mediation hearing. The law requires a mediator to resolve the dispute within thirty days after the referral or any longer period to which the parties may agree in writing. If the issue in dispute is settled, the dispute will be resolved in mediation (Employment and Labour Relations Act (No.6) of 2004: sect, 86 (3) [a], [b] and 86 (4).

While mediation is acknowledged as useful in resolving conflicts in wider dimensions [20:282, 26:1, 27], in Tanzania mediation is well-known in resolving labour disputes. Information about whether or not the method is applied in managing students' interpersonal conflicts in higher leaning institutions is limited and hence, knowledge about how students' interpersonal conflicts are handled is inadequate. This article explores experiences of deans of students responsible for managing students' interpersonal conflicts in the higher learning institutions in Tanzania. The article particularly examines the nature of students' interpersonal conflicts and whether or not mediation is used in resolution process. 


\section{THEORETICAL FRAMEWORK}

"Successful conflict resolution effort depends on how well concerns of both parties in conflicts are satisfied" [25]. The dual conflict concern theory explains two basic concerns of the conflicting parties or disputants: attaining concern for personal goals achievement and attaining the other party's concern for goals achievement [28]. The theory suggests that both concerns (oneself or personal concern: high or low and, the other party's concern: high or low) which operate at the same time and arising from inside oneself and from the social environment, are systems of pressure that affect the party's choice of strategies to interpersonal conflict management such as dominating, accommodating, avoiding, compromising and collaborating or integrating [28:37, 29, 30:12]. Examples of the party's concerns for goals achievement and strategies that may be adopted are depicted in Figure 1:

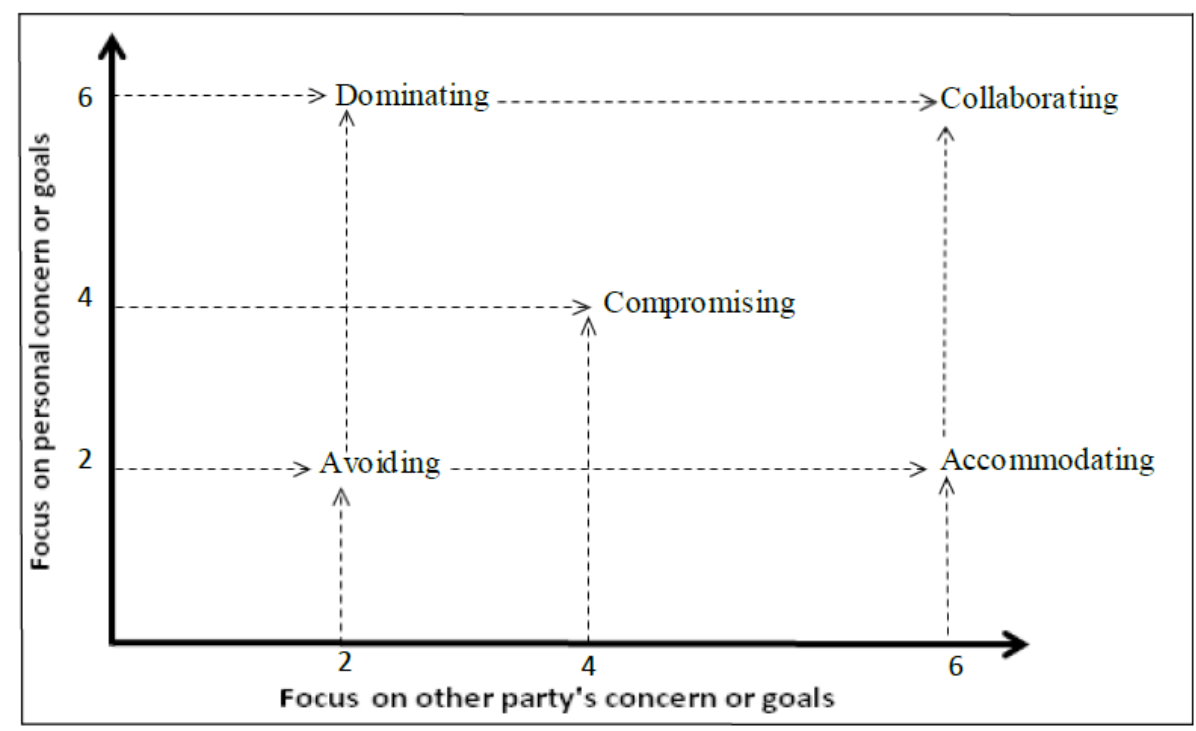

Figure1. Party's concerns and possible strategies in conflict management

The two parties' concerns dimensions for goals achievements and possible strategies to be adopted can also be well described in Table 1:

Table1. Concerns of the parties, combination and strategies in conflict management

\begin{tabular}{|l|l|l|}
\hline \multicolumn{1}{|c|}{ Concern } & \multicolumn{1}{c|}{ Combination } & \multicolumn{1}{c|}{ Strategy } \\
\hline High personal concern \& low concern for others & Win-lose (I win and you lose) & Dominating \\
\hline Low personal concern \& high concern for others & Lose-win (I lose and you win) & accommodating \\
\hline Low personal concern \& low concern for others & Lose-lose(I lose and you lose) & Avoiding \\
\hline Some personal concern \& some concern for others & We both win some, lose some & Compromising \\
\hline High personal concern \& high concern for others & Win-win (I win and you win) & Collaborating \\
\hline
\end{tabular}

Source: [1:33]

The highlighted concerns and combinations (Figure 1 and Table 1) which form a five-style approach or strategy to interpersonal conflict management have been illustrated in numerous studies [see for example, 1:5, 7:279, 25:33,35, 31, 32:196, 33]. High self concern and low concern for the other party's interests or goals corresponds to a win-lose combination. This concern leads to an adoption of a dominating or a competitive strategy to conflict management. The dominating or competitive strategy is characterised with forcing personal feeling, aggressive behaviour, blaming the other, threatening and use of power as is the case with strike and lockout practices. The dominating strategy is usually applied in arbitration and adjudication processes where each party strives to protect its own position or interests at the expense of the other party and hence, the strategy is unlikely to resolve interpersonal conflicts amicably

The second combination of low concern for personal or self interests in favour of the other party's concerns, goals or needs, directs to an accommodating or sometimes called obliging or yielding strategy to conflict management. The strategy is useful when continued relationship is aspired or when the conflict issue is less important or when the party realises that it is incorrect with the conflict issue $[1,5]$. 
The third combination of low concerns for both parties' interests leads to avoiding or withdrawing which is a passive response to conflict situation, assuming that the conflict will diminish or wither away over time. Although the style is important in reducing high tension or when parties have more pressing issues, adoption of this style may be attributed to little regard for oneself or lack of knowledge about how to manage conflict [25].

The forth combination (win-some and lose-some) with a compromising strategy often involves splitting the differences whereby each party accepts a midway position to give up something to attain at least a partial resolution of a conflict issue. Thus, some concerns for one party and the other party are taken into account. A compromising party is viewed to be typically "less dominating, less obliging, less avoiding and less collaborating" although it is argued that partial resolution of conflict may not be satisfactory to either party [25:35].

The fifth combination (win-win) leads to a collaborating or an integrating strategy to conflict management. The strategy takes into account high concern for both parties' interests. It is viewed that a collaborating strategy to conflict management allows open expression of feelings, information sharing, exploration of the issue and finding out a solution that fully satisfy both parties. The style is based on consensual decision making, involving negotiation, mediation and other collaborative or integrative processes [1:6, 25:34-5].

This article is underpinned by an integrative or a collaborating approach to conflict management with a central focus on mediation as a means for resolving students' interpersonal conflicts in higher learning institutions. As an integrative approach to managing conflict; mediation takes into account concerns of both parties in conflict and this is very important in conflict resolution. As pointed out elsewhere in this article, "successful conflict resolution efforts depends on how well the interests or concerns of both parties in conflicts are satisfied" [1:6, 25:34-5].

\section{Materials ANd Methods}

As widely acknowledged the nature of the research objective (s) usually determines the type of research approach or design to be employed [34:34, 35:51]. Considering the central research objective of exploring experiences of deans of students in handling students' interpersonal conflicts, the materials on which the article is centred were collected through a qualitative research approach [36, 37, 38:7, 39] between May 2017 and August 2018.

\subsection{Study Participants and Sampling}

Given the nature of the research objective, a specific knowledgeable sample was liable to provide reliable information. As contended by Devi [40,41], in social science research, persons who are deemed more knowledgeable about the issues under investigation are interrogated and desired information is collected. Thus, the study participants were mainly deans of students from higher learning institutions in Tanzania. From experience, deans of students are responsible for controlling and managing students' affairs including resolving students' interpersonal conflicts in the higher learning institutions in Tanzania. The participants were deemed knowledgeable, and hence appropriate to the study.

Selection of the study participants was done through purposive sampling technique. Although the purposive sampling does not give equal chance to every unit in the population to be included in the study, the technique is considered to be very useful when the study needs a sample of experts in the field under research [42:93, 43:312]. As widely acknowledged, in the purposive sampling technique, the items of the sample are selected in accordance with some purposive principle and hence, the probability of inclusion of some units of the universe in the sample is very high while the probability of exclusion of the other is very low [40, 41]. Participants were selected on the basis of experiences in dealing with students' interpersonal conflicts and willingness to participate in the study [44-46].

Thus, twenty six deans of students from the regions with substantial number of institutions of higher learning in Tanzania were involved in the study. The regions included: Dar es Salaam, Zanzibar, Dodoma, Morogoro, Mwanza, Iringa and Mbeya. Deans of students varied in terms of educational level, background and experience in dealing with students' affairs. A majority (sixteen informants) had background training in education and Psychology. Two had background training in public administration and those with training in Sociology and Social Work were four respectively. 
Participants' work experience ranged from three to twelve years. Four deans had experience of three years in work, nine had worked for eight years, four had ten years experience while nine deans had worked for twelve years. The participants' work experience and training backgrounds are shown on Table 2.

Table2. Study participants, work experience and training background

\begin{tabular}{|l|l|l|}
\hline \multicolumn{1}{|c|}{ Code } & \multicolumn{1}{|c|}{ Work experience } & \multicolumn{1}{c|}{ Background and level of training } \\
\hline 1 & 8 Years & BA Educational Psychology (BA Epsy) \\
\hline 2 & 12 Years & Bachelor Degree in Social Work (BSw) \\
\hline 3 & 3 Years & Masters of arts in Public Administration (MA Padm) \\
\hline 4 & 12 Years & Masters of Arts with Education (MA Ed) \\
\hline 5 & 3 Years & BA Educational Psychology (BA Epsy) \\
\hline 6 & 3 Years & Bachelor of Arts with Education (BA Ed) \\
\hline 7 & 12 Years & MA Sociology (MA Soc) \\
\hline 8 & 12 Years & MA Social Work (MSw) \\
\hline 9 & 8 Years & Masters of Arts with Education (MA Ed) \\
\hline 10 & 8 Years & MA Social Work (MSw) \\
\hline 11 & 10 Years & Masters of Arts with Education (MA Ed) \\
\hline 12 & 12 Years & MA Sociology (MA Soc) \\
\hline 13 & 12 Years & BA Educational Psychology (BA Epsy) \\
\hline 14 & 8 Years & BA Educational Psychology (BA Epsy) \\
\hline 15 & 10 Years & Bachelor Degree in Social Work (BSw) \\
\hline 16 & 12 Years & BA Public Administration (BA Padm) \\
\hline 17 & 8 Years & MA Educational Psychology (MA Epsy) \\
\hline 18 & 10 Years & MA Sociology (MA Soc) \\
\hline 19 & 8 Years & Masters of Arts with Education (MA Ed) \\
\hline 20 & 3 Years & Bachelor of Arts with Education (BA Ed) \\
\hline 21 & 12 Years & BA Sociology (BA Soc) \\
\hline 22 & 8 Years & MA Educational Psychology (MA Epsy) \\
\hline 23 & 12 Years & Masters of Arts with Education (MA Ed) \\
\hline 24 & 10 Years & Masters of Arts with Education (MA Ed) \\
\hline 25 & 8 Years & Masters of Arts with Education (MA Ed) \\
\hline 26 & 8 Years & PhD Educational Psychology (PhD Epsy) \\
\hline
\end{tabular}

\subsection{Data Collection and Methods}

To gain insights and experiences regarding students' interpersonal conflicts and resolution, semistructured interviews were conducted with twenty six deans of students. In addition to the interviews, two focus group discussions (each with six participants from among the twenty six interviewees) were conducted via a week long workshop held in Dar es Salaam region. Focus group discussions were useful in checking consistencies and clarity of the collected information. In the course of the research, interviews and focus group discussions were complemented by a thorough review of secondary materials.

\subsection{Data Analysis}

Semi-structured interviews and information from focus group discussions were analyzed thematically in the course of research. Analysis of data involved three stages suggested by Miles and Huberman which are: data reduction, organising reduced data, interpreting analysed data and drawing conclusion [47]. During the data reduction stage, semi-structured interviews were transcribed. The second stage involved reduction of data whereby data were reduced from recurrent patterns and organised. Central themes and sub-themes were generated from the data. The final stage involved interpretation of the analysed data and drawing conclusion and recommendations.

\section{Results}

\subsection{Nature of Students' Interpersonal Conflicts}

One of the central foci underpinning this article is to examine the nature of students' interpersonal conflicts in higher learning institutions in Tanzania. Informants' narratives revealed different types of interpersonal conflicts that are prevalent in higher leaning institutions. Interpersonal conflicts emerged 
are of three categories: conflicts relating to sexual relationship, matrimonial or family related conflicts and those relating to theft of materials including money, books and computers.

\subsubsection{Sexual Relationship Conflicts}

According to the informants' expositions, sexual relationship conflicts mainly involved the female students against male student counterparts in most cases following breaking down of their pre-marital sexual relationship. Such conflicts were associated with physical attack, abusive language and intimidation as revealed in the following quoted examples:

"... Recently a female student came to my office, the student complained about being frequently insulted by a male student after the breaking down of sexual relationship with him ... after listening to the two conflicting parties, I counselled them to adopt good behaviour and guided them on how they could live harmoniously by respecting one another and abiding by the Institute regulations as students" (interview informant, 1:2017).

"Students interpersonal conflicts are very common in many universities. In my university I remember one incidence where an in- service female student came to complain in my office for being sexually exploited by a male student. The student reported that her partner had stopped relationship with her after falling in love with a young girl friend. She complained that she used to provide him with material support including money and she was getting academic help from him. The in-service female student was also anticipating getting married to the young male student although the male student was reluctant, claiming that she was older than him" (Focus Group Discussion, 1: 2018).

From the informants' narratives it was also learnt that some of the sexual relationship conflicts reported to deans of students were from external individuals against some male students, particularly those who lived off campus. The following informants' narratives are exemplary of such interpersonal conflicts:

Many students' conflicts are reported by the in-campus students but some of them have been reported to my office by the outsiders ... I have experience of resolving a conflict that involved a male parent who lived in a nearby village against a male student, suspecting him to have been indulging in love affairs with his young daughter: an in-campus student" (Interview informant, 5: 2017).

"Last month, a parent came to report about our off-campus male student who refused to marry his pregnant girlfriend - also an off campus student. The parent complained that, the male student made his young daughter pregnant and refused her after making her pregnant" (interview informant, 4: 2017).

According to the informant's narratives, the male student used to study with the girl friend who claimed to fall in-love with him after revealing to him her terrible story of rape before she joined the University. The boy fell in love with the girl.

\subsubsection{Matrimonial Conflicts}

Interview with informants also disclosed students' conflicts relating to matrimonial or marital issues, including failure by some students to return back home after joining universities, failure to provide financial support to wives left back home and negligence of children. The following quotations are examples of narratives of the disclosed cases:

"Last month, wife of one student came to complain to my office that her husband who is a student in this Institute had never gone back home since he joined a Diploma course two years ago ..." (Interview informant, 2: 2018).

"I have been handling many students' conflicts .... some of them are very complex, I have an experience of a conflict that involved a social worker who came to report one of our students who left his child at the orphanage centre for the past three years without any communication with the child or social welfare officer" (Interview informant, 10: 2018). 
Investigating the use of Mediation in Resolving Students' Interpersonal Conflicts in Higher Learning Institutions in Tanzania

\subsubsection{Theft Related Conflicts}

Some of the conflicts that were disclosed related with stolen students' materials such as computers, mobile phones, clothes, shoes, money and books. According to the informants, most of these conflicts involved male students and were frequently associated with insults and personal attacks as the following quoted examples indicate:

".Conflicts relating to theft are very common here. It is very difficult to stay idle in the office for the whole month without receiving a conflict relating to theft involving money, book, computer or mobile phones ... These conflicts mainly involve male students ... some of them used to offer some gifts to their girl friends while financially they are poor" (Interview informant, 15: 2018).

"Stealing properties is like a fashion among the male students. When examinations are very close such cases increase. Some students particularly male, steal the money for the purpose of paying tuition fees and giving their girl friends" (Focus Group Discussion, 2: 2018).

\section{APPROACHES TO INTERPERSONAL CONFLICT RESOLUTION}

Informants' experiences in handling students' interpersonal conflicts were also explored. From the informants' narratives, the approaches to interpersonal conflicts resolution were mainly guidance and counseling. In the observed institutions of higher learning, guidance and counseling services were provided by deans of students in their respective offices. Few conflicts particularly those relating with murder were reported to police for further legal proceedings.

According to the informants, disciplinary procedures could also be applied to some of the students' conflicts, particularly those relating with fighting and theft. Disciplinary procedures highlighted were suspending students from studies and discontinuing them from studies. From the informants' narratives it was noted that in the management of students' interpersonal conflicts, sometimes more than one approach could be used. The informants' replies regarding the methods used in resolving students' interpersonal conflicts are summarized in Table 3.

Table3. Participants' replies on the use of different conflict resolution methods

\begin{tabular}{|l|l|l|}
\hline \multicolumn{1}{|c|}{ Conflict resolution approach } & \multicolumn{1}{c|}{ Informants' reply } & \multicolumn{1}{c|}{ Number of informants } \\
\hline Termination or discontinuation & Sometimes used & Ten \\
\hline Suspension & Sometimes used & Six \\
\hline Avoidance & Rarely used & Two \\
\hline Arbitration & Never used & Twenty six \\
\hline Counseling and guidance & Frequently used & Twenty six \\
\hline Mediation & Never used & Twenty six \\
\hline Litigation & Sometimes used & Four \\
\hline
\end{tabular}

Examples of the reported interpersonal conflicts, students / persons involved as well as the method adopted to resolve the conflicts are shown on Table 4.

\begin{tabular}{|l|l|c|c|c|l|}
\hline \multicolumn{1}{|c|}{ Interpersonal conflicts } & \multicolumn{2}{|c|}{ Students / people involved } & \multicolumn{2}{c|}{ Conflict resolution method } \\
\hline $\begin{array}{l}\text { Male student's refusal to marry a } \\
\text { pregnant girl friend and stopping } \\
\text { relationship with her. }\end{array}$ & M-M & M-F & F-F & F-M & \\
\hline $\begin{array}{l}\text { A female student insulted by a male } \\
\text { student }\end{array}$ & $\checkmark$ & & & $\begin{array}{l}\text { The students were counselled by dean } \\
\text { of student }\end{array}$ \\
\hline $\begin{array}{l}\text { A wife (non-student) and her never } \\
\text { returned home husband (student). }\end{array}$ & & & & $\checkmark$ & $\begin{array}{l}\text { The students were counselled and } \\
\text { guided to behave well }\end{array}$ \\
\hline $\begin{array}{l}\text { A male student neglecting a child } \\
\text { to orphanage center for ming and guiding the couples to }\end{array}$ \\
\hline $\begin{array}{l}\text { Male parent reporting young } \\
\text { daughter (student)' involvement in } \\
\text { love affairs with an older student }\end{array}$ & & $\checkmark$ & & & $\begin{array}{l}\text { Guidance and counseling on good } \\
\text { parenting. Referred the case to Social } \\
\text { welfare office and continued to make } \\
\text { follow up }\end{array}$ \\
\hline
\end{tabular}

Key: $M=$ Male, $F=$ Female 


\section{DISCUSSION}

As revealed from the findings, the methods relied upon by deans of students in the process of resolving students' interpersonal conflicts in the higher learning institutions observed were mainly counselling and guidance. The findings revealed non-application of mediation and peer mediation in particular in resolving students' interpersonal conflicts in the higher learning institutions.

Little emphasis on the use of mediation can be explained by the background training of the interviewed deans of students. As indicated on Table 2, there was no dean of student with background training in Mediation. The informants' background training were mainly in Sociology, Social work, psychology and education in which guidance and counselling courses have been also offered in Tanzania. Through experience, mediation courses have been offered in the Department of Labour Studies at the Institute of Social Work in the country and, mediators have been employed to deal with labour disputes and not students' interpersonal conflicts.

While the use of mediation and peer mediators in resolving students' interpersonal conflicts seemed to be inactive in the studied institutions, in numerous studies the use of the methods are acknowledged as very useful in resolving students' interpersonal conflicts [see for example, 20:282, 26:1, 27, 48]. Stressing on the use of mediation and students' peer mediation in resolving students' interpersonal conflicts in this article does not mean downgrading the importance of guidance and counselling services offered in institutions of higher learning. As observed in some studies, guidance and counselling are important toward assisting individual students, particularly young students in lower classes with inadequate knowledge about the courses to be selected, for exploring their feelings in their career interests and helping them in subject choice [49-53].

Moreover, guidance and counselling are useful for exploring hidden and burning problems from students who appear to be lonely or unhappy and uncover the sources for their depression, anxiety and lack of interest in life [54]. In such circumstances, students may consult deans as counsellors to discuss their individual problems.

However, the central argument in this article is that with regard to students' interpersonal conflicts; guidance and counselling are likely to be inappropriate and hence, unlikely to provide an amicable or peaceful lasting solution (s) to the disputants or conflicting parties. In line with this argument is the view that "guidance and counselling as adult imposed models are ineffective in warranting the desired positive change in students' behaviour and in preparing them for more serious future interpersonal conflicts" [18].

For effective resolution of interpersonal conflicts, mediation "which entails involving the conflicting parties actively in the resolution of their own conflict" [18] seems to be a more appropriate and reliable method. For instance, for the interpersonal conflict that involved wife (non-student) and her never returned home husband (student), the parties could be brought together to a point that they could work out their differences with the aid of a third party (mediator).

Mediation and peer mediation in particular, have been more successful in students' conflicts resolution in the developed countries where they have been widely used although in developing countries (including Tanzania), limited data still exists on effectiveness of the methods [18, 24, 55]. However, as acknowledged in some studies, conflict resolution through mediation and peer mediation minimizes interpersonal conflicts and increases the attitude of assisting others with conflict, reduces aggressiveness and increases competence in conflict resolution [18:631, 56].

\section{CONClusion}

The focus of this article has been on how students' interpersonal conflicts in higher learning institutions in Tanzania are resolved. The article examined whether mediation was applied in resolving students' interpersonal conflicts in the higher leaning institutions. The findings revealed that students' interpersonal conflicts were handled by deans of students with limited knowledge and skills in mediation despite long work experience as indicated on Table 2. Peer mediation in particular was never used because the frequently used methods were mainly guidance and counselling.

\section{RECOMMENDATIONS}

On the basis of the findings and discussion, there is an urgent need to promote the use of mediation 
acknowledged as appropriate in resolving students' interpersonal conflicts by; firstly, orienting and equipping deans of students with requisite knowledge and skills in mediation for the purpose of resolving students' interpersonal conflicts amicably. Secondly, there is an urgent need of orienting deans of students on how to identify specific types of conflicts that may be resolved through mediation and those that may be resolved through other approaches such as counselling and guidance.

Thirdly, deans of students should strive to play the role of mediators while resolving students' interpersonal conflicts. Fourthly, students pursuing higher learning education should be imparted with knowledge and skills in mediation to enable them to play the role of peer mediators in resolving their fellow students' interpersonal conflicts. In this regard, students' interpersonal conflict resolution through peer mediators may involve "cadre approach" or few trained students to save as peer mediators for the whole institution or using "total student approach" which entails teaching all students how to manage conflict constructively [18]. In this respect, deans of students should also play the role of orienting the students in their respective institutions on how to participate actively in students' interpersonal conflicts resolution.

And lastly, students should be empowered to resolve their interpersonal conflicts through innovative ways in order to avoid the consequences of being suspended, discontinued from studies or the shortfalls of adopting rigid positions which may lead them into violence practices which are usually detrimental to interpersonal relationship and to acquisition of quality education.

\section{REFERENCES}

[1] Picard CA. Mediating interpersonal and small scale group conflict. Ottawa: The Golden Dog Press; 2002.

[2] John G, Oetzel, Stella T-T. Face concerns in interpersonal conflict. a cross-cultural empirical test of the face negotiation theory. Communication Research. 2003;30(6):599-624.

[3] Knapp ML, Daly JA, editors. Handbook of interpersonal communication. 3 ed. Thousand Oaks: Sage Publications; 2002.

[4] Rahim M, Afzalur. Managing conflict in organizations. New Brunswick [NJ]: Transaction; 2011; Available from: http://site.ebrary.com/id/.

[5] Picard CA. Practising insight mediation. Toronto: University of Toronto Press; 2016.

[6] Hocker JL, Wilmot WW. Interpersonal conflict. Madison, Wisconsin: Brown \& Benchmark; 1995.

[7] Ting-Toomey. S, Ge Gao, Paula Trubisky, Zhizhong Yang, Hak Soo Kim, Sung-Ling Lin, et al. Culture, face maintenance, and styles of handling interpersonal conflicts: a study in five cultures. International Journal of Conflict Management. 1991;2(4):275-96.

[8] Cooley. CH. "Conflict and co-operation". Chapter 4. In social process. New York: Charles Scribner's Sons: $35-42.1918$.

[9] Coser LA. The functions of social conflict. New York: Routledge; 1956.

[10] Dahrendorf R. Toward a theory of social conflict. The Journal of Conflict Resolution. 1958;2(2):170-83.

[11] Dahrendorf R. Class and class conflict in industrial society. Stanford: Stanford University Press; 1959. 336 p.

[12] Marx K, Engels F. Manifesto of the communist party. New York: International Publishers; 1948.

[13] Adelman HS, Taylor L. School counsellors and school reform: new direction. In Professional School Counselling, 5 (4), p.235-249 2002.

[14] DeMato DS, Curcio CC. Job satisfaction of elementary school counsellors: a new look. In Professional School Counselling, 7 (4), p.236-245. 2004

[15] Hernandez TJ, Seem SR. A safe school climate: a systemic approach and the school counsellor. In Professional School Counselling, 7 (4), p.256-262. 2004.

[16] Johnson DW, Johnson RT, Dudley B. Effects of peer mediation training on elementary school students. Mediation Quarterly. 1992;10:89-99.

[17] Kerega PA. Understanding the industrial economy and workers' rights in Tanzania: prospects and challenges under a new industrial strategy. Journal of Human Resources Management and Labor Studies. 2018; 6(1):1-12.

[18] Turnuklu A, Kacmaz T, Sunbul D, Ergul H. Does peer-mediation really work? effects of conflict resolution and peer-mediation training on high school students' conflicts. Procedia Social and Behavioral Sciences. 2009(1):630-8.

[19] Smith S, W, Daunic AP, Miller MD, Robinson TR. Conflict resolution and peer mediation in middle schools: extending the process and outcome knowledge base. Journal of Social Psychology. 2002; 142(5): 567-86. 
[20] Cappelletti M. Alternative dispute resolution processes within the framework of the world-wide access-tojustice movement. The Modern Law Review, 56(3), 282-296. Retrieved from http://www.jstor.org/stable/ 1096668. 1993.

[21] Scimecca JA. Theory and alternative dispute resolution: a contradiction in terms. In D. J. D. Sandole, H. vander Merve, Conflict resolution theory and practice: integration and application (pp. 211-221). Manchester, UK: Manchester University Press. 1993.

[22] Goldberg SB, Sander FEA, Rogers NH. Dispute resolution: negotiation, mediation, and other processes. Boston: Mass. Little Brown; 1992.

[23] Shamir Y. Alternative dispute resolution approaches and their application in water management: a focus on negotiation, mediation and consensus buiding 2001-2013 11 June 2018. Available from: http://unesdoc.unesco.org/i.

[24] Johnson DW, Johnson RT, Mitchell J, Cotton B, Harris D, Louison S. Effectiveness of conflict managers in an inner-city elementary school. Journal of Educational Research. 1996;89(5):280-7.

[25] Johnson P, E. Conflict and the school leader: expert or novice. Journal of Research for Educational Leaders (JREL). 2003;1(3):28-45.

[26] Bercovitch J. The structure and diversity of mediation in international relations. In Bercovitch J., Rubin J.Z. (eds) mediation in international relations. Palgrave Macmillan, London. 1992.

[27] Goldberg SB, Frank E.A. Sander, Nancy H. Rogers, Sarah Rudolph Cole. Dispute resolution: negotiation, mediation, and other Processes. 6, editor. New York: Aspen Publishers; 2012.

[28] Vallacher RR, Peter T. Coleman, Andrzej Nowak, Lan Bui Wrzosinska, Larry Liebovitch, Katharina G. Kugler, et al. Attracted to conflct: dynamic foundations of destructive social relations. New York: Springer Heidelberg; 2013.

[29] Vliert EVD. Complex interpersonal conflict bahaviour: theoretical frontiers. Hove and New York: Taylor and Francis; 1997.

[30] Blake RR, Mouton JS. The managerial grid: the key to leadership excellence. Houston: Gulf Publishing Company; 1964.

[31] Rahim MA. A measure of styles of handling interpersonal conflict. Academy of Management Journal. 1983(26):368-76.

[32] Kim K, Sik, Kim G, Chul, Song S, Hwi. Conflct management and governance in the transpot sector in Korea: The Korean Transport Institute; 2014.

[33] Rahim MA. Managing conflict in organizations. New York: Praeger; 1986.

[34] Silverman D. Doing qualitative research : a practical handbook;Second edition. 2nd ed. Thousand Oaks: Sage; 2005. xv, 395 p. p.

[35] Beri CG. Marketing research. 4, editor. New-Delhi: McGraw Hill Publishing Company; 2008.

[36] Corbin J, W, Strauss A. Basics of qualitaive research. 3 ed. CA: Sage: Thousand Oaks; 2014.

[37] Dahlgren L, Emmelin M, Winkvist A. Qualitative methodology for international public health. Umeå: Umeå International School of Public Health, Epidemiology and Public Health Sciences, Umeå University; 2007.

[38] Maxwell JA. Qualitative research design: an interactive approach. London: Sage Publications; 2005.

[39] Kiaga AK. Blaming the other woman: rural housegirls and urban employers on identity, labour and migration in Tanzania. University of Minnesota, USA; 2007.

[40] Devi L. Encyclopedia of social science Research. New Delhi: Anmol Publication Institute for Sustainable Development 1997.

[41] Kothari CRK. Research methodology: methods and techniques. Eastern Limited: Wiley; 1985.

[42] Daniel J. Sampling essentials: practical guidelines for making sampling choices. Thousand Oaks: Sage; 2012.

[43] Polit DF, Beck CT. Essentials of nursing research: appraising evidence for nursing practice. 7, editor. Philadelphia: Wolters Kluwer Health/Lippincott Williams \& Wilkins; 2010.

[44] Maxwell JA. Qualitative research design: an interactive approach. Thousand, Oaks, CA: Sage. ; 2013.

[45] Creswell JW. Qualitative inquiry and research design. Thousand Oaks, CA: Sage; 2013.

[46] Bernard HR. Social research methods: qualitative and quantitative approaches. 2 ed. Sage: Thousand Oaks, CA; 2013.

[47] Miles MB, Huberman AM. Qualitative data analysis: an expanded sourcebook. 2 ed. Thousand Oaks: CA:Sage; 1994.

[48] Abdi MS. A religious oriented approach to addressing FGM/C among the Somali Community of Wajir, Kenya. FRONTIERS Report. 2007. 
[49] Jan H, Mattoo MI. Educational guidance and counselling for students of education BEd, MEd, M.A ed New Delhi: Educreation Publishing; 2018.

[50] Kochhar SK. Guidance and counselling in colleges and universities. New Delhi: Sterling Publishers. 2003.

[51] Elkind D. Schools take on duties once held by parents. In the Education Digest, 47, p.16-18. 1990.

[52] Stead GB. The school counsellor's role. In Educamus, 33 (5) p.13-15.Steinberg, L. \& Morris, A.S. (2001) Adolescent development. In Annual Review of Psychology, 52, p.83-110. . 1987.

[53] Kameen MC, Robinson EH, Rotter JC. Coordination activities: a study of perceptions of elementary and middle school counsellors. In elementary school guidance and counselling, 20, p.97-1041985.

[54] Sederholm GH. Counselling young people in school: a hand book on social work and Student counselling. London: Jesca Kingsley Publishers; 2003.

[55] Bell KS, Coleman KJ, Anderson A, Whelan PJ. The effectivenss of peer mediation in a low-ses rural elementary school. Psychology in the Schools. 2000;37(6):505-16.

[56] Jones ST. Conflict resolution education: the field, the findings, and the future. Conflict Resolution Quarterly. 2004;22(1-2):233-67.

\section{AUTHOR'S BIOGRAPHY}

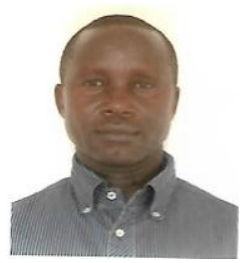

Dr. Polycarp Africanus Kerega is a lecturer and the Head of Department of Labour Studies at the Institute of Social Work in Dar es Salaam, Tanzania. He holds a diploma in education, a post-graduate diploma in Law, Mediation and Arbitration as well as MA and $\mathrm{PhD}$ in Sociology. He currently does a post-doctorate research focusing on "female domestic labourers and fertility control in Dar es Salaam" His areas of interests include: industrial sociology, conflict management, human rights, gender and labour studies.

Citation: Polycarp Africanus Kerega. "Investigating the use of Mediation in Resolving Students' Interpersonal Conflicts in Higher Learning Institutions in Tanzania" International Journal of Humanities Social Sciences and Education (IJHSSE), vol 6, no. 1, 2019, pp. 32-42. doi: http://dx.doi.org/10.20431/23490381.0601004 .

Copyright: (c) 2019 Authors. This is an open-access article distributed under the terms of the Creative Commons Attribution License, which permits unrestricted use, distribution, and reproduction in any medium, provided the original author and source are credited. 